\title{
Trends and Challenges in Development of Continuing Vocational Education and Training in Russia
}

\author{
Olga V. Borisova ${ }^{a}$, Dinara G. Vasbievaa ${ }^{\text {, Natalya I. Malykh }}{ }^{\mathrm{b}}$, \\ Sergey A. Vasnev ${ }^{c}$ and Nadezhda N. Vasneva ${ }^{d}$
}

aFinancial University under the Government of the Russian Federation, RUSSIA; 'DThe Russian Foreign Trade Academy of the Ministry for Economic Development of the Russian Federation, RUSSIA; 'Institute of Public Administration and Management (IPAM), RUSSIA;

${ }^{d}$ National Research Nuclear University, Moscow Engineering Physics Institute (MEPHI),

RUSSIA

\section{ABSTRACT}

The paper discusses the modern trends and challenges in the development of continuing vocational education and training in the Russian Federation. Particular attention is paid to the prospects for its development in the higher educational institutions of Russia. The key methods of the study are descriptions, observations and generalisations which are used to analyze the problem. They allow to verify the results of the study. The changes in the number of organizations providing services in continuing vocational training, the number of students and population figures for Russia were studied. The levels of education obtained in the country, the importance of continuing vocational education and training and key factors influencing its development were examined. The authors proved the need of taking into account the specifics of professional development, retraining and business education programs when using the techniques and approaches to learning process and knowledge evaluation.

KEYWORDS

Continuing vocational education and training, development of education, training in higher educational institutions, internet-based courses
ARTICLE HISTORY

Received 15 September 2016 Revised 17 November 2016 Accepted 22 November 2016

\section{Introduction}

Urgency of the problem

The rapid socio-economic changes of recent years in relation to "the development of the job market and the labor market require changing the quality of training of specialists who possess not only special knowledge but also specific qualities that

\section{CORRESPONDENCE O. V. Borisova $\triangle$ jalo-jalo@mail.ru}

(c) 2017 O. V. Borisova et al.

Open Access terms of the Creative Commons Attribution 4.0 International License apply. The license permits unrestricted use, distribution, and reproduction in any medium, on the condition that users give exact credit to the original author(s) and the source, provide a link to the Creative Commons license, and indicate if they made any changes. (http://creativecommons.org/licenses/by/4.0/) 
ensure their competitiveness and professional mobility". (Fedorov \& Tretyakova, 2016).

The Russian higher education services market in the sphere of continuing vocational education and training is being transformed. Until recently, consumers went to universities in order to obtain a state-recognized diploma. On 1 September 2013, the Ministry of Education and Science of the Russian Federation revoked these diplomas for programs related to continuing vocational education and training (Federal Law «On education in the Russian Federation», 2012). This had a negative impact on the higher education services market. The citizens turned out to be willing to pay money for the state-recognized diploma, but did not consider the options for the purchase of a diploma of a particular university. First of all, this is due to the fact that the significance of this diploma in professional circles is poorly understood.

Since 2011 the higher education services market has been significantly affected by the merger of several large universities which provide many sectors of the Russian economy with personnel. The number of universities has decreased, and continuing vocational education and training programs entered a new phase in their development.

Nowadays, the demand for continuing vocational education and training programs has reduced dramatically in many universities, which causes a significant damage to higher schools because these programs make it possible for them to generate additional income. Many universities face acute problems of modernization of this education direction and an increase in its attractiveness to a potential customer since "students know the resulting product must be qualified and able to compete in the marketplace". (Kusumaningrum et al., 2016). In the modern era of globalization and economic integration the innovative production needs qualified personnel capable to rapid adaptation to modern conditions of production, having a wide range of the professional and personal competences possessing vital labor values. (Zholdasbekova et al., 2016).

The aim of this study was to investigate the factors influencing the development of continuing vocational education and training. Within the broad theme, the research had a number of specific objectives:

- to examine the development of continuing vocational education and training;

- to look into the problems arising from the implementation of continuing vocational education and training programs by examples of Russian of economic universities.

The practical significance of the study is to determine the main directions of development of universities that implement continuing vocational education and training programs.

\section{Literature Review}

The works of some scholars laid foundation for much research focusing on the issues of continuing vocational education and training. The common issues related to the development of continuing vocational education and training were investigated by T.V. Matveeva (2007), A.P. Parakhonsky \& E.A. Venglinskaya (2009), V.V. Kravchenko (2010), V.S. Kvaginidze, O.V. Murzina, N.A. Dudnik, F.A. Pukhnaty (2011), N.A. Sineva (2012), A.V. Krasilnikov \& L.I. Krasilnikova (2012), A.M. Bakshtanin \& A.S. Siman (2015). The background to this type of education were studied by S.S. Mikhailova (2013), V.A. Korytov \& A.V. Semenikhina (2007), T.G. Mukhina, E.V. Koposov \& V.V. Borodachev (2013), and the major factors contributing to its development were researched by N.V. Rozenberg \& E.I. Tyurin (2013), E.I. Rau (2016), O.V. Borisova \& D.G. Vasbieva (2016). 
The problems of the development of continuing vocational education and training in international practice were investigated by G.A. Trubin (2012), L.F. Krasinskaya (2011) studied the features of the development of teacher's continuing vocational training in technical university. L.K. Gurieva \& M.E. Kabisov (2009) did research into the problem of regional specifics of continuing vocational education. A.M. Pyrsky (2012) identified the major directions of functioning of continuing vocational education and training in universities. The research of some issues of using gadgets in the learning environment was conducted by O.V. Borisova et al (2016a, 2016b).

These works and materials of the study have made significant contributions to the development of contemporary pedagogy. They demonstrate the level of development of continuing vocational education and training and make it clear there is a wide range of problems. The research of these works makes it possible to define the major problems encountered by universities when implementing the programs of continuing vocational education and training, which is the subject of our study.

\section{Materials and Methods}

During the study the following methods were used:

- theoretical methods: analysis, synthesis, generalization and logical method;

- empirical methods: observation, description, measurements and comparisons.

This research consists of four stages.

At the first stage the levels of education existing in Russia were studied, which made it possible to determine the position of continuing vocational education and training in this structure.

At the second stage the dynamics of the number of organisations providing continuing vocational education services, student body as well as overall population that are potential consumers of these services were studied.

At the third stage the research into the continuing vocational education and training programs, which are being implemented in Russia, was done.

The purpose of the fourth stage was to study the major problems and challenges in implementation of continuing vocational education and training programs and to define prospects for its further development, which allowed the authors to draw well-founded conclusions.

\section{Results and Discussions}

\section{The model of the modern educational system in the Russian Federation}

The model of the modern educational system in the Russian Federation was created according to the Federal Law "On Education in the Russian Federation" (2012). This normative document indicates the levels of education existing in the Russian Federation (Fig. 1). 


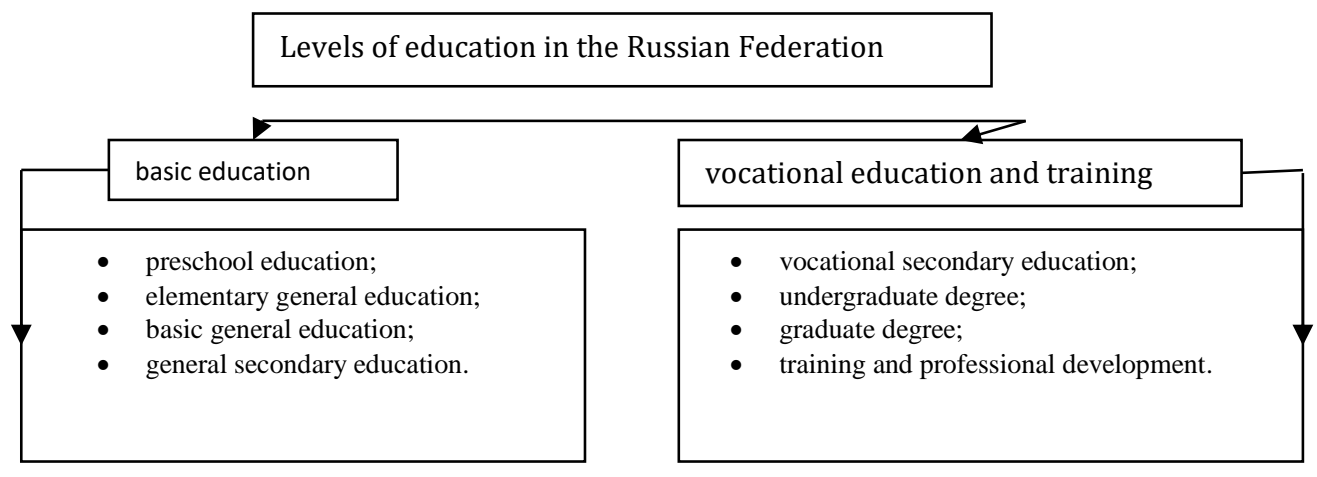

Figure 1. Levels of education in the Russian Federation

Continuing vocational education and training is not assigned to a separate item. These services can be provided by educational institutions of all levels of professional qualifications. Currently, most secondary technical schools and higher educational institutions have professional development and retraining programs.

\section{Continuing vocational education and training in Russia}

Continuing vocational education and training is a professional training provided in addition to the secondary or higher education. The basic continuing vocational education and training regulations are indicated in article 76 of the Federal Law "On Education in the Russian Federation" (2012). So the law says that the objectives of this kind of education are as follows:

— meeting educational and professional needs;

- citizen's professional development;

- ensuring compliance of the qualification with changing conditions of professional work and social environment.

The Federal Law also specifies the types of continuing vocational education and training. They are divided into professional development and retraining programs. These programs are designed for those who are getting higher qualifications or have already obtained university degrees. They allow to increase the level of professional qualifications for citizens who have higher qualifications or to master a new type of professional activities.

\section{Continuing vocational education and training programs implemented by Russian higher education institutes}

Nowadays, standard types of continuing vocational education and training programs are being developed and approved. Professional standards, requirements for appropriate qualifications and requirements of the federal state educational standards provide the basis for their contents. Qualification requirements are specified in the competency catalogue containing the list of qualification requirements for professional knowledge and skills that are used by the employee for the performance of his/her duties. The training process and its duration are subject to the terms of the education agreement. Some programs stipulate an internship. Each training program includes an assessment whose type is defined by the organisation. According to the results of the training program the attendees receives a certificate or diploma of professional retraining. 
The volume of the educational services consumed is changing regularly. The official statistics for these services is missing. Demand for them can only be determined by calculating the working-age population figures and taking into account the rules set forth in the regulation of the Russian Federation "On compulsory further education courses" triennially.

Let's look at the changes that are taking place in relation to the delivery of educational services. It should be noted that they are provided by the state and municipal agencies, as well as private ones, which is why the authors think it wouldn't make economic sense to determine total revenue or funding for a specific period. The picture is more justified if one determines the number of educational establishments delivering the services of continuing vocational education and the number of trainees in various modes of study.

The study is based on the data of the Russian Federal State Statistics Service. The population figures increased by an average of $0.1 \%$ per year between 2005 and 2016 as shown in Fig. 2. At the same time, the number of citizens aged 20 to 60 decreased by $0.36 \%$ per year.

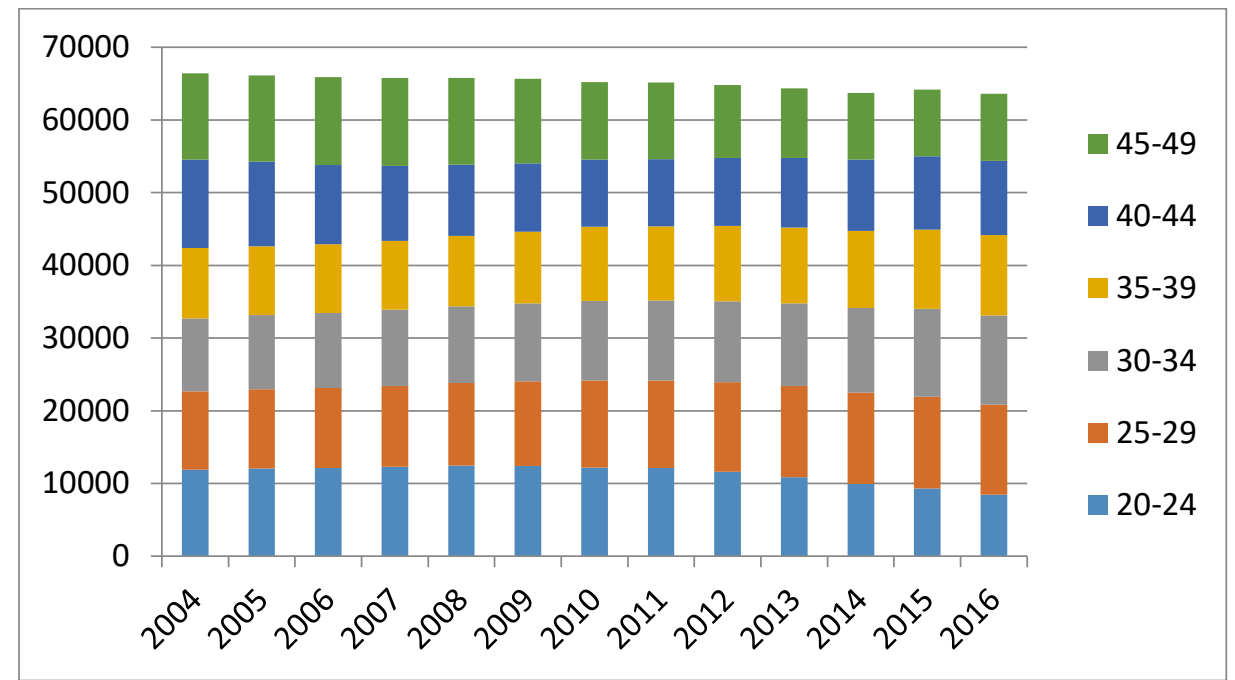

Source: Russian Federal State Statistics Service. URL: http://www.gks.ru/

Figure 2. Population by age group, in mln people

It should be noted that these citizens are active consumers of services in the sphere of continuing vocational education and training, as they are related to the economically active population. Approximately $80 \%$ of trainees attending the programs of retraining are at the age of 25-45 years old, since they keenly feel the lack of professional knowledge as a result of changes in the regulatory and legal acts and the macroeconomic situation, as well as transformation of methods of doing business. With regard to this group of the population, the rate of growth in the number of citizens aged $25-45$ is $0.63 \%$. Consequently, the demand for continuing vocational education and training should be stable or increase slightly. But in fact this does not happen. To understand the reasons for what is happening, we have analyzed the number of educational institutions, which have the right to deliver services of continuing vocational education and training and the number of trainees (Fig. 3). 


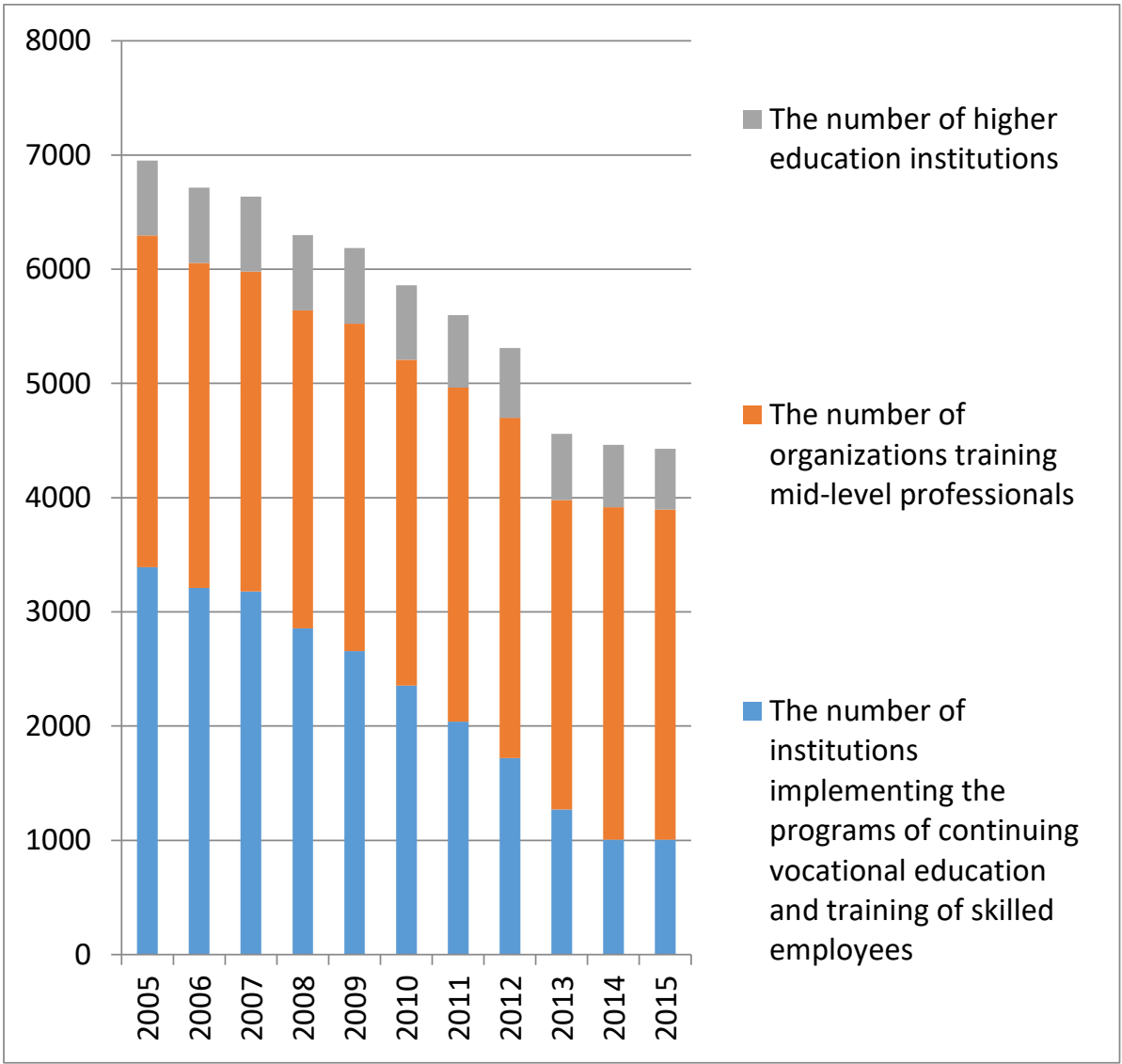

Source: Russian Federal State Statistics Service. URL: http://www.gks.ru/

Figure 3. Changes in the number of the institutions implementing the programs of continuing vocational education and training in Russia

The table shows that the number of institutions implementing the programs of continuing vocational education and training of skilled employees reduced during the analyzed period at an average rate of $21 \%$ annually. At the same time, the number of organizations training mid-level professionals remains unchanged. The average value of this index increased by $0.04 \%$ per annum during the analyzed period. The number of higher education institutes reduced by an average of $2 \%$ annually. These findings are quite logical and reflect the ongoing policy of the Russian Federation in the field of education to increase the number of vocational schools and reduce the number of universities.

Training can be provided to students in vocational and higher education institutions through the programs of continuing vocational education and training, changes in their number being shown in Fig. 4. In this regard, we have analyzed the enrollment of these institutions, which showed that the number of the trainees decreased in all institutions. So, the number of educational institutions implementing training programs for workers and employees fell by $17 \%$ a year, mid-level professionals - by $1.64 \%$. The number of students enrolled in higher education institutions reduced by $3.7 \%$. It should be noted that the rate of drawdown in the number of students of various modes of study are different. The number of students of 
evening classes declined significantly, because they have difficulty combining it with work. In the past two years, higher education institutions and vocational education institution do not accept students enrolled in the externship program. As for the fulltime and extra-mural students, the reduction in their number is less significant. However, no one claims completely that the educational institutions lose their appeal, because the number of potential applicants are reducing.

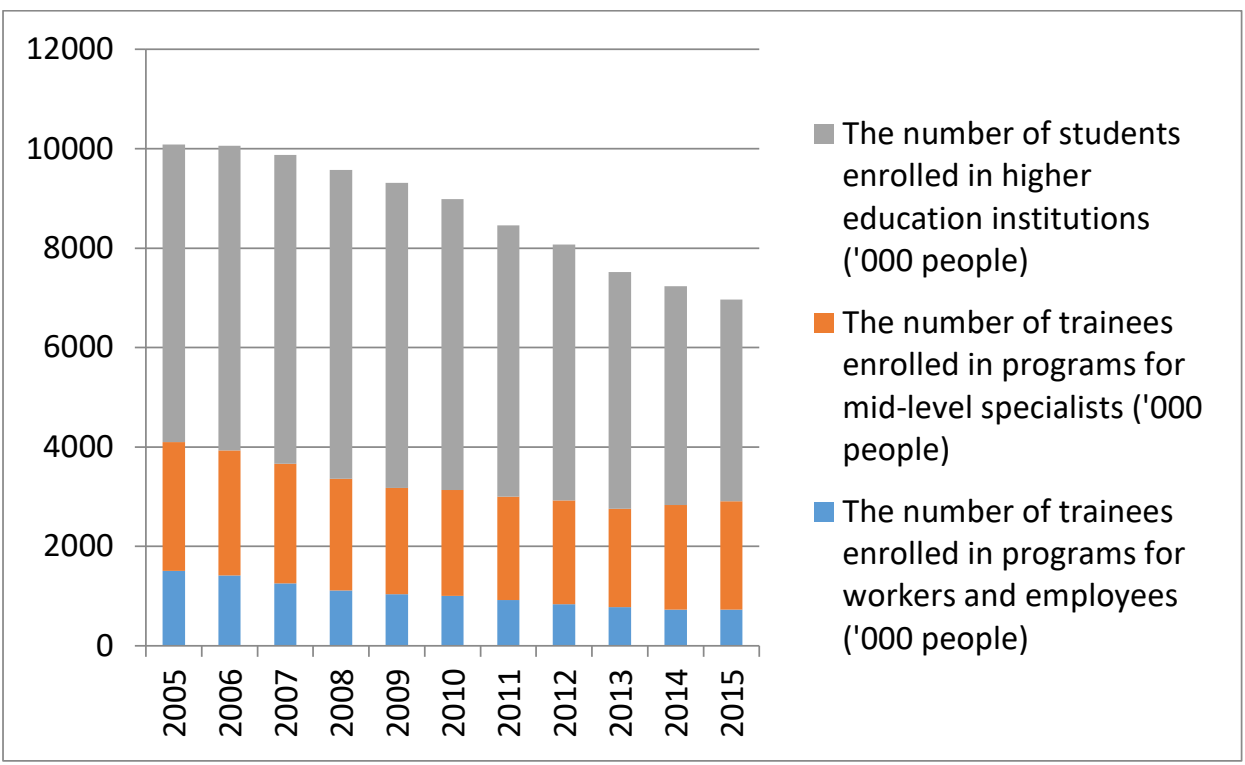

Source: Russian Federal State Statistics Service. URL: http://www.gks.ru/

Figure 4. Changes in the number of the students in Russian specialised secondary school and higher education institutes

Higher education institutes are currently developing two types of services of continuing vocational education and training. Let's consider them in more detail. The first type of service is professional retraining. Its course is 900 hours of total workload. The number of hours for in-class learning ranges on average from 250 to 500 hours. The rest of the time allowed for self-study. After completing the program, trainees obtain a retraining degree. In addition, some universities issue a certificate of equivalence. At the end of the program, trainees are entitled to conduct a new type of professional activity. In many universities the programs of continuing vocational education and training are implemented by special departments. This is due to the specifics of these programs. The range of programs is quite wide and depends on the specific university.

The second type of the programs is a professional development program. Its main objective is increasing the education level of workers. It is aimed at improving the employee's skills and knowledge. In accordance with the law these programs are designed for 16 or more hours. They allow you to improve the professional knowledge of a particular job. Due to the fact that some areas go through a rapid change, such programs make it possible upgrade the employees' existing knowledge. Professional development programs include hands-on trainings and workshops on specific subjects.

According to the authors, the business education programs should be spun off into a separate unit, as their duration varies and can not be aligned with professional 
development and retraining programs. These programs are popular with people having higher qualifications and work experience in a particular area. Some of these business education programs involve the selection of the candidates according to the criteria enacted in the Russian Federation, which is not required in the two previous programs. This is the critical distinction between them.

By and large, our study suggests that it is advisable to divide the programs of continuing vocational education into three rather than two types. This can be represented in Fig. 5.

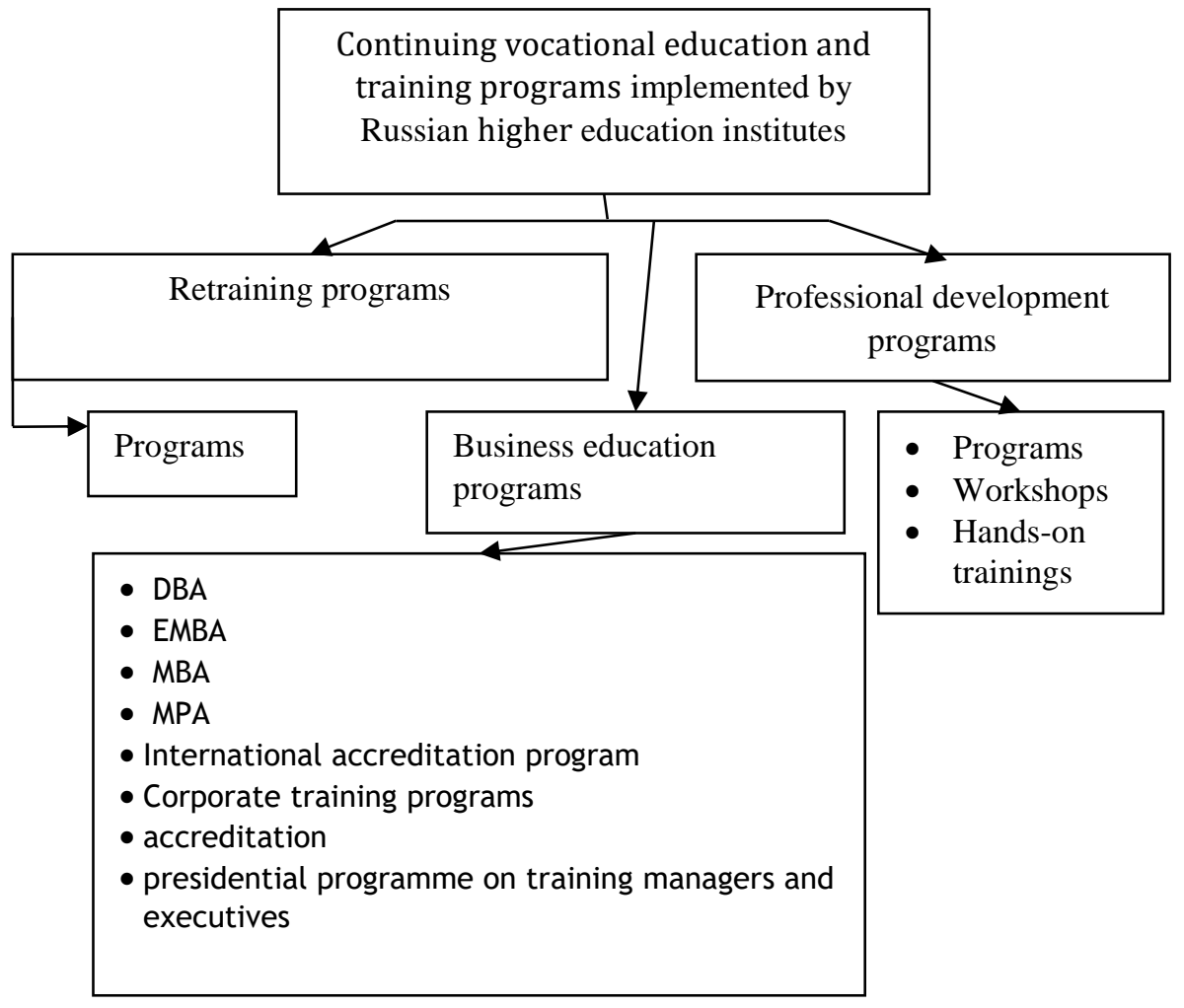

Figure 5. Continuing vocational education and training programs implemented by Russian higher education institutes

Successful implementation of continuing vocational education and training programs by Russian universities is related to the differences "in the methods, forms, approaches to the organization of educational process and evaluation of trainees' knowledge". In the majority of Russian higher education institutes approaches to teaching undergraduates and graduates are similar to those in the courses of continuing vocational education and training (Borisova \& Klimova, 2015). According to the authors, the approach should be sufficiently different. Firstly, in addition to theoretical issues, practical aspects of the chosen topic should be considered in depth. Secondly, an achievement test should be built on the basis of the psychological characteristics of adult learning. The authors believe that it is advisable to use game situations, which will identify how well each participant master the training toolkit.

Professional development and retraining in a number of areas is the trend of the modern society. Educational services on these directions are provided in secondary and higher educational institutions. The survey showed that the number of educational 
institutions which have the right to provide this type of services as well as the number of trainees enrolled in professional development and retraining programs in higher education institutes are declining. This resulted from the number of problems identified in the study.

\section{Conclusion}

The study showed that continuing vocational education and training programs should be divided into professional development, retraining and business education programs since their requirements are different. The potential of further implementation of each program depends mainly on the level of satisfaction of trainees' interests within the framework of standards of the Ministry of education and science of the Russian Federation. On the other hand, it is crucial to take into account the specifics of these programs when using the techniques and approaches to the learning process and knowledge evaluation.

\section{Disclosure statement}

No potential conflict of interest was reported by the authors.

\section{Notes on contributors}

Olga V. Borisova is $\mathrm{PhD}$, Associate Professor of Financial University under the Government of the Russian Federation, Moscow, Russia.

Dinara G. Vasbieva is PhD, Associate Professor of Financial University under the Government of the Russian Federation, Moscow, Russia.

Natalya I. Malykh is PhD, Associate Professor of the Russian Foreign Trade Academy of the Ministry for Economic Development of the Russian Federation, Moscow, Russia.

Sergey A. Vasnev is PhD, Associate Professor of the Russian Presidential Academy of National Economy and Public Administration (RANEPA); Institute of Public Administration and Management (IPAM), Moscow, Russia.

Nadezhda N. Vasneva is PhD, Associate Professor of National Research Nuclear University, Moscow Engineering Physics Institute (MEPHI), Moscow, Russia.

\section{References}

Bakshtanin, A.M. \& Siman, A.S. (2015).Features of additıonal education. Bulletin of educational and methodological association on environmental engineering andwater conservation. 7 (7). 5-8.

Borisova, O.V., Vasbieva, D.G., Frolova, V.B. \& Merzlikina, E.M. (2016a). Usıng Gadgets in Teachıng Students Majorıng in Economics. IEJME-Mathematics Education. 11(7), 2483-2491.

Borisova, O.V. \& Klimova, I.I. (2015). Innovative methods and models of training students majoring in Finance and Economics. Moscow: VividArt, 174.

Borisova, O.V., Vasbieva, D.G., Malykh, N.I., Vasnev, S.A. \& Bírová, J. (2016b). Problem of Using Innovative Teaching Methods for Distance Learning Students. International Electronic Journal of Mathematics Education, 11(5), 1175-1184.

Borisova, O.V. \& Vasbieva, D.G. (2016). Prospects for the development of continuing vocational education on the basis of Russian universities. Slavonic Pedagogical Studies Journal, 5(2), 443-454.

Federal Law «On education in the Russian Federation» dated 29.12.2012. N 273-FL. (2012). Educational platforms. Direct access: http://dopedu.ru/online-edu.html

Fedorov, V.A. \& Tretyakova, N.V. (2016). The Development of Vocational Pedagogical Education in Russia (Organizational and Pedagogical Aspect). International Journal of Environmental and Science Education, 11(17), 9803-9818.

Gurieva, L.K. \& Kabisov, M.E. (2009). Modern trends and problems of development of continuing vocational education in Russian regions. Direct access: http://sciencebsea.narod.ru/2009/ekonom 2009/gurieva sovremen.htm.

Korytov, V.A. \& Semenikhina, A.V. (2007). The history of development of further vocational education and training. Pedagogical journal of Bashkortostan, 3(10), 72-85. 
Krasilnikov, A.V. \& Krasilnikova, L.I. (2012). Modern problems of additıonal vocational education. Pedagogical education and Science, 5, 85-88.

Krasinskaya, L.F. (2011). Development of continuing vocational education of teachers of a higher technical school. Man and education, 1(26), 4-7.

Kravchenko, V.V. (2010). Main trends in development of continuing vocational education abroad. The World of Science, Culture and Education, 5, 160-162.

Kusumaningrum, I., Hidayat, H., Ganefri, Anori, S. \& Dewy, M.S. (2016). Learning Outcomes in Vocational Education: a Business Plan Development by Production-Based Learning Model Approach. International Journal of Environmental and Science Education, 11(18), 11917-11930.

Kvaginidze, V.S., Murzina, O.V. \& Dudnik, N.A. (2011). The strategy of development of continuing vocational education and training with the use of innovative technologies. Mining Informational and Analytical Bulletin, 3, 78-83.

Matveeva, T.V. (2007). Modern State and Directions of Innovative Development of the Additional Professional Education. Regional Economy: the Theory and the Practice, 17(56), 67-77.

Mikhailova, S.S. (2013). From history of development of further vocational education and training. Actual problems of the humanities and natural sciences, 11(2), 205-209.

Mukhina, T.G., Koposov, E.V. \& Borodachev, V.V. (2013). The history and prospects for the development of continuing vocational education in Russia. Privolzhsky Scientific Journal, 3(27), 123-128.

Parakhonsky, A.P. \& Venglınskaya, E.A. (2009). Modern trends in the development of continuing vocational education. International journal of education, 3, 153-167.

Pukhnaty, F.A. (2011). Directions and problems of development of secondary vocational education in the printing industry. Business law. Economic and legal journal, 6, 191-194.

Pyrsky, A.M. (2012). Conceptual directions for functioning and developing of continuing vocational education in universities. Bulletin of Pushkin Leningrad State University, 3(1), 99-106.

Rau, E.I. (2016). Major factors promoting and suppressing the development of continuing vocational education. Proceedings of the International Scientific Conference, Altai Technical University after Polzunov I.I.,160-163.

Rozenberg, N.V. \& Tyurin, E.I. (2013). Key development factors of further vocational education in the modern society. Science, Society. State, 3(3), 224-232.

Sineva, N.A. (2012). Development problems and prospects of further vocatıonal education in conditions of its reforming. Bulletin of Baikal State University, 4, 16-18.

Trubın, G.A. (2012). Trends in the development of continuing vocational education abroad. Bulletin of Tumen State University, 8. Direct access: http://cyberleninka.ru.

Zholdasbekova, S., Nurzhanbayeva, Z., Mavedov, R., Saipov, A., Zhiyentayeva, B. \& Tlemissova, A. (2016). Didactic Conditions of Improvement of Pedagogical Personnel Training at Higher Education Institutions to Dual Education in the System of VET. International Journal of Environmental and Science Education, 11(18), 12345-12359. 